\title{
Granny Solidarity: Understanding Age and Generational Dynamics in Climate Justice Movements
}

\author{
MAY CHAZAN \\ Trent University, Canada \\ MELISSA BALDWIN \\ Trent University, Canada
}

\begin{abstract}
Since the 2018 Intergovernmental Panel on Climate Change (IPCC) report, a global shift in consciousness has taken place around the urgency of the Earth's climate crisis. Amidst growing panic, teenagers are emerging as key leaders and mobilizers, demanding intergenerational justice and immediate action. They are, however, often depicted as lone revolutionaries or as pawns of adult organizations. These representations obscure the complex and important ways in which climate justice movements are operating, and particularly the ways in which dynamics of age intersect with other axes of power within solidarity efforts in specific contexts. This article explores these dynamics, building on analyses of intersectional and intergenerational solidarity practices. Specifically, it delves into detailed analysis of how the Seattle group of the Raging Grannies, a network of older activists, engaged in Seattle's ShellNo Action Coalition, mobilizing their age, whiteness, and gender to support racialized and youth activists involved in the coalition, and thus to block Shell Oil's rigs from travelling through the Seattle harbour en route to the Arctic. Drawing from a pivotal group discussion between Grannies and other coalition members, as well as participant observation and media analysis, it examines the Grannies' practices of solidarity during frontline protests and well beyond. The article thus offers an analysis of solidarity that is both intergenerational and intersectional in approach, while contributing to ongoing work to extend understandings of the temporal, spatial, cognitive, and relational dimensions of solidarity praxis.
\end{abstract}

KEYWORDS climate justice; climate change; intergenerational; age; aging; solidarity; gender; race 


\section{Introduction}

In October of 2018, signalling a shift in global consciousness, the Intergovernmental Panel on Climate Change (IPCC), a group of the world's leading climate scientists, reported that humans have 12 years to reduce carbon emissions by $45 \%$ in order to avoid triggering a series of feedback loops that would make future life on Earth untenable (Brake, 2018). This declaration of climate crisis amplifies widespread messages of urgency by scientists, land and water protectors, Indigenous Elders, public figures, and activists (Brake, 2018; Water Docs, 2019b). Amidst this growing panic, teenage activists, like Greta Thunberg, Autumn Peltier, and Jamie Margolin, are emerging as world leaders, raising their voices at global summits and inciting mass mobilizations (Burton, 2019; Water Docs, 2019a). ${ }^{1}$

Post 2018, youth leaders are capturing media attention with sophisticated analyses and complex demands. They are calling for deep transformation of global economic systems, away from capitalist-colonial extraction, toward different ways of organizing societies, economies, and lives (Margolin, 2019; Peltier, 2018; Tait, 2019). Ultimately, they are demanding intergenerational justice: calling on older generations, particularly those who have reaped the benefits of wealth accumulation and technological advancement over their lifetimes and who now hold the balance of global power, to radically change their actions, beliefs, and lifestyles now in order to prevent the mass suffering and extinction of generations to come (Eisen, Mykitiuk \& Scott, 2018; Winter, 2017). They are repeatedly questioning how older people in positions of power - many of them parents and grandparents - can continue to protect their own comforts knowing that they are putting future life at risk.

While these youth leaders are truly remarkable, dominant media representations of youth-led climate justice uprisings depict them as lone revolutionaries within a global movement replete with generational divisions (e.g., Cohen, 2019; Tait, 2019). ${ }^{2,3}$ Such representations are, however, not

\footnotetext{
${ }^{1}$ There are many critiques of how media representations centre white activists, like Greta, as leaders, while erasing Indigenous, Black, and brown activists (Frazer-Carroll, 2019). Indeed, there are many prominent youth activists of colour in the climate justice movement, including Tokota Iron Eyes, Mari Copeny, Artemisa Xakriabá, Ridhima Pandey, Alexandria Villaseñor, Ayakha Melithafa, Xiuhtezcatl Martinez, Isra Hirshi, and others (Burton, 2019). Further, while the current visibility, media prominence, and vast numbers of youth mobilizing for climate justice might be new, youth mobilization around climate change far predates 2018 (e.g., Winona LaDuke and Severn Suzuki addressing the UN in 1977 and 1992, respectively (Honor the Earth, 2019; United Nations, 2017)).

${ }^{2}$ Climate justice is "a broad and unsettled concept" and framework for global resistance that exposes the unequal and inequitable impacts of climate change (Black, Milligan \& Heynen, 2016, p. 286). Diverse climate justice movements centre social injustice rooted in inequality between groups who have most benefited from global extractive development, and those who are and will be most impacted. They also expose how those in positions to make immediate and material changes towards radically reducing carbon emissions are also those who profit from extractivism. Climate justice discourses link "environmentalism" to intersecting analyses of
} 
based on grounded analysis of intergenerational and age dynamics within climate justice organizing, and thus they fall short. The complex age dynamics at play are obscured amidst this global imaginary, as are the particularities of how intergenerational solidarities are understood and practiced in different contexts. ${ }^{4}$ Meanwhile, the ways in which intergenerational politics and relationships are practiced in response to the climate crisis hold enormous repercussions for future life on Earth (Winter, 2017). A number of key questions thus emerge: What roles are older people playing in climate justice mobilizations and coalitions? How are intergenerational solidarities understood and practiced within different contexts? How are dynamics of age and generation intersecting with other axes of difference - race, gender, geography, ancestry - within these climate justice efforts? This article explores these questions, drawing from the authors' longstanding research with older women activists across North America.

We investigate the ways in which one group of older women, the Seattle chapter of the Raging Grannies, ${ }^{5}$ worked in solidarity as part of a multifaceted anti-oil campaign - specifically through their actions at protests, roles in organizing spaces, and commitments to personal (un)learning. Our analysis builds from five years of research with a network called the Raging Grannies. Elsewhere we have written about how some Raging Grannies groups, as groups of predominantly older (60s through $80 \mathrm{~s}$, and hence of the early baby

global wealth disparity, ongoing (settler) colonialism, capitalist extraction and profiteering, border imperialism, racism, patriarchy, and more (Mersha, 2018; Margolin, 2019).

${ }^{3}$ In widespread media representations, these teen activists are often depicted alone, speaking to immense audiences of adults who hold power (e.g., Tait, 2019; Water Docs, 2019a). Moreover, youth leaders are frequently described as the "solution" or the "hope," while older people are represented in opposition as the "problem." This divisive rhetoric further erases intergenerational dynamics and obscures the roles and relationships of younger and older people within this movement (see Winter, 2017). This centering of youth as inspiring revolutionaries in the post2018 climate response has been critiqued as polarizing young environmentalists in opposition to a homogenous generation of environmentally destructive Boomers (e.g., Cohen, 2019).

4 "Solidarity," a hopeful political concept with roots in labour movement organizing, is frequently deployed as a model of political engagement that holds possibilities for working across differences in power toward common goals for social change (Gaztambide-Fernández, 2012; Featherstone, 2012). "Solidarity" has been critiqued and reimagined, particularly by transnational feminist and Indigenous scholars, who challenge assumptions of similarity among "women" or across Indigenous/settler positions, paying explicit attention to solidarities across differences in power and privilege (Mohanty, 2003) and offering compelling re-imaginings of relational and interdependent solidarities (Snelgrove, Dahmoon \& Corntassel, 2014).

${ }^{5}$ The Raging Grannies are a network of older women activists who mobilize for a variety of social and environmental causes. The Raging Grannies first organized in 1987 in Victoria (Canada), as peace activists imaginatively and humorously protesting the appearance of U.S. submarines carrying nuclear warheads in the Victoria harbor. Their humour captured the imaginations of other older women across Turtle Island: now, over 100 groups span the continent, and some even exist abroad (see www.raginggrannies.org). These groups, though selfdirected and distinct, share the tactic of mobilizing ageist stereotypes of "little old ladies" in parodic performances, with colourful shawls, large hats, aprons, and other props (Roy, 2004; Sawchuk, 2009; Goldman, Chazan, \& Baldwin, 2018). 
boomer cohort) white settler women, are practicing solidarity-building with Indigenous-led movements in the Canadian context (Chazan, 2016); about assumptions of older women's feminist politics, specifically presumptions of their limited intersectional analysis or awareness (Chazan \& Baldwin, 2016); and about motivations for engaging in activisms in later life more broadly (Chazan, Baldwin, \& Whattam, 2018).. We focus here on the Seattle Raging Grannies' roles in the ShellNo Action Coalition, which in 2015 organized a series of sophisticated and impactful land and water actions, protesting Arctic oil extraction and the presence of Shell Oil's drilling rigs in the port of Seattle, on Coast Salish, $x^{w} m ə \Theta k^{w} \partial \dot{y} \partial m$ (Musqueam), and Skwwxwú7mesh (Squamish) territories. Specifically, we explore some of the complex age dynamics within this climate justice coalition, ${ }^{6}$ in which over 15 groups explicitly organized around a logic of intersectional and intergenerational solidarity. By this logic, those most impacted by climate change (youth, Indigenous communities, people of colour) were intended to lead, while those occupying relative positions of privilege (white, middle class, and so on, including the Raging Grannies) were meant to offer tactical support.

Drawing closely from research at the Raging Grannies biannual international "Unconvention" held in Seattle in 2016, we consider what we can learn from the Raging Grannies' practices, as well as from their coalitional partners' reflections and feedback. In so doing, we extend analysis of age and intergenerational dynamics (as they intersect with other systems of power and difference) within climate justice mobilizations specifically (Greenfield, 2019), and within relationships of solidarity more generally (Binnie \& Klesse, 2012). We argue that, during the 2015 ShellNo actions, the Raging Grannies mobilized their age together with their gender and whiteness to confer protection from the police, for themselves and for more targeted coalition members. We also explore how dynamics of age, gender, and race informed their roles and relationships in other organizing spaces beyond frontline protests.

\section{Context and Methodology}

The Seattle Raging Grannies Unconvention opened with a panel of predominantly younger, Indigenous and/or racialized activists: eight nonGranny activists from the ShellNo Action Coalition, with whom the Grannies had been nurturing relationships since before the 2015 actions. Rather than open their gathering with presentations from Grannies themselves - many of whom are seasoned older activists who continue to work tirelessly in many

\footnotetext{
${ }^{6}$ This is one of many protests against oil extraction, profiteering, and pipelines, as part of the climate justice movement, and as intertwined with Indigenous land protection and sovereignty, and and anticapitalist challenges to extreme wealth (e.g., challenges to the Dakota Access Pipeline at Standing Rock and by the Unist'ot'en people; see Rowe \& Simpson, 2017; Noisecat \& Spice, 2016).
} 
movements - these older, mostly white settler women chose to position themselves as listeners first. We take this observation as our starting point for this article.

Our analysis focuses on this panel discussion, in which the Grannies posed a critical question to themselves as a movement: how could they (i.e., Raging Grannies) do solidarity better? The panel was moderated by a member of Seattle Raging Grannies, who we call "Granny X" to maintain her privacy, and included the following coalition members (listed in speaking order): Panelist 1, a younger woman of colour and founder of Women of Colour Speak Out; Panelist 2, an Indigenous (Tlingit, Haida, and Tsimshian) woman who identified as a spiritual activist and has directed both Idle No More Washington and Native Women Rising; Panelist 3, a young Black woman who was organizing with Got Green, a racial and climate justice organization; Panelist 4, a young man of colour who organized with Rising Tide Seattle; Panelist 5, a younger white woman activist, writer, and co-founder of 350 Seattle; Panelist 6, an older white woman who was part of the Red Noses Affinity group, which offered legal and frontline action support and police liaison; and Panelist 7, a white woman who identified as a spiritual activist and engaged in direct action. The discussion centred the perspectives of the first three panelists, which Granny $\mathrm{X}$ explained was to recognize that racialized, Indigenous and youth activists are often the most impacted, hardest working, and least recognized within activist coalitions. Panelists reflected thoughtfully on what they had learned through their experiences, to an audience of approximately 100 Grannies from over 12 geographically diverse groups.

The ShellNo Action Coalition was organized with an understanding of intergenerational and racial equity and justice, and a recognition that the impacts of climate change are uneven (Kaijser \& Kronsell, 2014; Margolin, 2019; Mersha, 2018). Though this mobilization took place before the pivotal 2018 IPCC report, this coalition (like others globally) already centred the needs, perspectives, and voices of young, Indigenous, and racialized activists. The actions to block the passage of Arctic drilling rigs took place on land, in water, and in mid-air. Coalition members organized through varied tactics: confident swimmers took to kayaks; Tlingit and Haida singers and drummers shared music, dance, and prayer on the deck of a renewable energy barge; artists created massive banners to close off a train terminal and elaborate lanterns to move through the water; and Raging Grannies locked themselves and their rocking chairs to train tracks. ${ }^{7}$

We base our analysis on several sources of information. First, at the UnConvention we recorded the two-hour opening panel discussion (with permission), offering the recording and transcript back to the organizers and

\footnotetext{
${ }^{7}$ For coverage of these actions, see Democracy Now, 2015; Kaplan, 2015; and Ryan, 2015.
} 
panelists. ${ }^{8}$ Most directly, our analysis draws on our close thematic readings of this transcript, including the moderator's comments and the question and answer period that followed. Second, we texture this analysis with close readings of media coverage of the ShellNo actions, including pieces from large news outlets as well as movement-generated social media. Third, we contextualize our analysis with our participant observation undertaken at other gatherings and actions. We are aware that our focus on the Raging Grannies within the ShellNo mobilization lends itself to a critique of how this could reinforce the prominence of white activists in a movement that is seeking to instead shift this power dynamic. Yet, we also believe that in the context of existing climate coalitions there is value in understanding how older white women are practicing solidarities across all forms of difference including instances in which their coalitional partners experience this as both meaningful and insufficient. We seek to understand the operations of whiteness in combination with age, gender, and so on within the ShellNo effort. Our example concerns "older" white women in solidarity with "younger" racialized and Indigenous activists, but we also recognize the important work of older Indigenous and racialized activists within climate justice struggles broadly and the need for more attention to their contributions (Meadows, Thurston \& Lagendyk, 2009; Water Docs, 2019b). Though ShellNo predated the 2018-2019 youth uprisings, the dynamics and lessons learned remain as relevant as ever.

\section{Doing Intergenerational and Intersectional Solidarities}

We turn now to our conceptual framework. We draw on a growing body of critical scholarship on "intersectional solidarities" - that is, political/social struggles carried out collaboratively by those who hold different privileges, oppressions, and positions vis-à-vis these struggles, and who explicitly seek to account for how these multiple intersecting axes of power inform their relationships and efforts (Bilge, 2011; Mohanty, 2003; Tormos, 2017). This work thus attends to difference - without erasing it or requiring "innocence and sameness as prerequisites" (Olwan, 2015, p. 90; Mohanty, 2003) - while also exposing the potential for epistemic violence and other nuanced workings of power within coalitional politics (e.g., Boudreau Morris, 2017; Snelgrove, Dhamoon \& Corntassel, 2014; Walia, 2012). While dynamics of gender, race, geography, ancestry, are class are centred within much of this intersectional solidarity work, power relations associated with age and generation are rarely incorporated into these analyses. At the same time, there exists a small body of scholarship on intergenerational solidarity, but much of this work is less engaged with critical decolonial and antiracist analyses

\footnotetext{
${ }^{8}$ This panel was a closed meeting as part of the Raging Grannies gathering, intended as a space for internal discussions of their practices and ongoing learning.
} 
(Binnie \& Klesse 2012; Cooper, 2014). This article's core conceptual contribution is therefore to offer one grounded analysis of solidarity practices that is both intersectional and intergenerational in approach (Chazan, 2016; Bilge, 2011).

We draw on scholarship that conceptualizes solidarity as praxis, understanding solidarity as a doing - as contingent and ongoing practices of forging relations through political struggle to challenge forms of oppression (Chazan, 2016; Gaztambide-Fernández, 2012). Attending to how age intersects with race, gender, and ancestry, we consider how a praxis of solidarity in the ShellNo coalition comprised not only one-off, frontline actions taken during protest, but also ongoing relationship-building behind the scenes, thus conceptualizing solidarity as a "long-term commitment to structural change" (Arvin, Tuck \& Morill, p. 19, cited in Flowers 2015, p. 35). Further, we consider how the Grannies' solidarity practices involved the internal work of grappling with dominant white settler epistemologies and destabilizing their own certainty (Boudreau Morris, 2017; Langley, 2018; Regan, 2010). We draw on Flowers, who argues that "solidarity means decentring ourselves... confronting the impulse to claim to know or have authority over a struggle" (2015, p. 35), and on Adele Sholock (2012), who explores how white settler activists might practice epistemic "uncertainty" to unbound their solidarities from colonial and white-centric logics.

As we consider how age shapes solidarity as praxis, we bring our analysis into dialogue with emerging scholarship on aging and social movements, and specifically on older women's roles in working for social change (e.g. Meadows et al., 2009; Chazan, Baldwin \& Whattam, 2018). Scholars in this area note how sexism and ageism (among other systems of power) shape older women's ways of organizing and experiences of discrimination, and they debunk dominant discourses of social movements as the domain of youth (Chazan, Baldwin \& Evans, 2018). Moreover, where other critical movements across North America are concerned (including intersectional feminist, anti-racist, anti-colonial, and anti-poverty movements), older white women are frequently assumed to dominate organizing processes with little awareness of their own privilege and limitations (e.g., Chazan \& Baldwin, 2016). Critiques of white-centric and racist "white feminism" are often specifically linked to age and applied unilaterally to older white women, even though this kind of "feminism" can certainly exist among younger white women as well (Chazan \& Baldwin, 2016; Cargle, 2018; Frazer-Carroll, 2019). By attending to dynamics of gender, race, and age concurrently, we engage with and intervene in some of these assumptions.

Most pertinently, we bring this conceptual frame - a critical intersectional and intergenerational analysis of solidarity - to scholarship on climate justice organizing: while there is widespread understanding that youth and future generations will be inequitably impacted, here too there has been little attention to how age operates and is mobilized within coalitional politics (Winter, 2017). In popular discourse, older generations ("Boomers") tend to 
be depicted as either helplessly vulnerable to the environmental crisis (e.g., Paterson-Cohen, 2017), or as apolitical, frail, indifferent, or "the problem" (e.g., Eisen, Mykitiuk \& Scott, 2018). Tropes of the old handing the responsibility of a burning future over to the young pervade (e.g., Council of Canadians, 2019). As Nicole Greenfield (2019) suggests, we urgently need further analysis of how intergenerational dynamics intersect with other systems of power within climate justice movements (see also Shell, 2019; Eisen, Mykitiuk \& Scott, 2018).

\section{Grannies on the Front Lines: Mobilizing Gender, Age, and Race}

When the Seattle Raging Grannies joined activists of all ages to protest at the frontlines of the 2015 ShellNo actions, they contested narratives of all Boomers as "the problem" in the climate crisis, and of older people as apolitical and frail (Patersen-Cohen, 2017; Sawchuk, 2009). In several actions, they mobilized their privilege as older white women along with ageist assumptions about their bodies in two strategic ways.

First, the Grannies practiced intergenerational solidarity by deploying their well-known "little old ladies" parody (their satirical protest performance of ageist and sexist stereotypes, intended to draw attention and subvert such assumptions) to divert media and police attention, allowing younger activists to carry on with other key organizing. In one prominent action, several Grannies locked themselves down on rocking chairs over train tracks in order to block oil trains from passing through to the port of Seattle. The Grannies dressed in feather boas, bright hats, aprons, and shawls, and hung photos of their grandchildren and great-grandchildren around their necks; they sat chained to their rocking chairs, knitting and drinking tea. One media account described the Grannies' rocker lockdown as a "visual victory," specifically describing how the eldest Granny "[wore] her standard granny uniform of sunhat and flowing skirt, wielding every one of her 92 years like a weapon. Being a Raging Granny is all about making the most of an older woman's moral clout" (Kaplan, 2015). This visual victory was also a tactical victory: panelists at the 2016 Unconvention explained that by holding the line in their rockers for many hours, the Grannies kept the police busy and freed up the younger activists to carry on with other organizing. As one panelist explained, the lock-down began with a larger group of younger activists chained to oil drums alongside the Grannies. As the police arrived, the Grannies insisted that they would stay to the end, which allowed the younger activists to carry out the next set of actions and avoid one more direct encounter with police. At the same time, the "how" of this diversion reveals important dynamics of age: the Grannies were making strategic choices of where, when, and how to resist based on their bodies (i.e., their bodily needs as older people as well as their white privilege and assumed frailty). Many Grannies would not have been able to participate in actions in kayaks, for 
instance, because of mobility challenges. Staying on land, being seated moreor-less comfortably in rockers for the five-hour protest (which ended in their arrest) best suited their bodily abilities and coincided with effective political strategy for the broader coalition. Their little old lady parody was thus more than just attention-grabbing; it linked to the needs, assumptions, and privileges that accompany their bodies, and made space for younger activists to carry out other coalitional work.

Second, the Grannies' mobilized their social positions not only to divert attention but also to confer protection to younger activists of colour specifically. Mobilizing ageist assumptions of older women (as frail, apolitical, and innocent), and recognizing that their whiteness protected them from disproportionate police brutality, the Grannies were the ones to stay on the tracks and be arrested. As Granny X explained, the Grannies anticipated that police would be relatively gentle with their old, white bodies, and that in their rocking chairs and aprons they would be deemed a very low threat. Knowing they would be treated better than any others in the coalition, which proved true, they stayed to relieve younger racialized activists from this police encounter. As the five Grannies held their ground, the police took their time to cut them free as delicately as possible. Unlike other younger and racialized organizers who were arrested and held during the course of the ShellNo actions, the five Grannies who were arrested were released immediately after processing. Panelist 6 , also an older white woman, explained:

[This] never happened before in my experience of doing anything. The Grannies were so gingerly treated when they were arrested. I was one of the police liaisons and I was told that we could send a couple of 'support' people with them in the van - they weren't going to be cuffed - to the police station!

Granny X further explained that their gentle treatment was in stark contrast to the police brutality inflicted upon young racialized people by the same officers:

It is one of the most important things Grannies can do, is to show up to these actions and protect younger activists of colour. If the Seattle Grannies have learned nothing else, we have learned that. We have terrible racist police in Seattle, terrible, racist, violent police. [...] They always treat the Grannies really nicely. So, if we are there, it's some protection for our friends.

Panelists and the Seattle Grannies alike felt this way of conferring protection was a most tangible expression of frontline solidarity and support to people of colour's organizing in general, and this sentiment was widely supported by the Raging Grannies in the audience. Indeed, when Panelist 1 responded to Granny X's assertion with the statement, "we need the white allies and our white elders to come and stand in front, to be that shield," the Granny audience cheered, many nodding eagerly. The Seattle Grannies knew that the 
combination of ageist assumptions and white privilege would likely protect them from serious danger, and they wielded these assumptions to act as a barrier.

What emerges, then, is that on the front lines, youth were not resisting alone. The ways in which panelists discussed the Raging Grannies' contributions suggest that the strategic roles these older women took on supported and bolstered the work of younger coalition members. As well, age, and its intersections with gender and race, was operating in many crucial ways to inform solidarity practices - ways that both subverted and mobilized ageist assumptions and aging bodies. Grannies mobilized their privilege as white women, a tactic often discussed in writings about solidarity across difference (e.g., Mohanty, 2003; Sholock, 2012), but they also deployed marginalizing age-based stereotypes, to ultimately divert attention from and confer protection to other coalition members. Moreover, the intergenerational nature of this coalition augmented the creativity and inventiveness of its tactics - tactics tailored to differing bodily abilities. What might have been assumed to be limiting about older age became a valuable tool to the intergenerational resistance.

\section{Grannies Behind-the-Scenes: Deepening Understandings and Practices of Solidarity}

The ShellNo coalition's frontline protests were successful at stopping the passage of Shell's oil rigs to the Arctic, in part because of intergenerationality and diversity of tactics. Yet, as the Unconvention panel explored, the coalition's workings were far from perfect. Our research revealed three aspects of how the Grannies' solidarity practices extended or could have extended beyond the frontlines: first, how the Grannies could have mobilized their intersecting age, race, and gender in behind-the-scenes organizing to confront racism and sexism within the coalition; second, how the Grannies did extend their solidarity through continuing relationships and by taking a posture of uncertain learning in the ShellNo panel; and third, how panelists also invited the Grannies to build solidarity with ancestors and generations unborn. We highlight how each of these temporal and spatial extensions of conceptualizing solidarity challenge assumptions of solidarity as confined to impermanent, strategic frontline actions. These shifts require deconstructing white settler certainties with continued attention to dynamics of age, gender, and race.

Panelists at the Seattle Unconvention's opening suggested that the Grannies could have further mobilized their positions and perceived moral authority to confront sexism and racism playing out behind the scenes within the coalition - but reflected that the Grannies did not fully take this on. For instance, these panelists noted that in organizing meetings there were a few "Toxic White Males" who manipulated their power and authority to try to 
control the actions of Indigenous and racialized organizers, and that these dynamics were not meaningfully confronted:

No one ever confronts the toxic white male, and because of that, the people of colour in the room, who are marginalized to begin with, they don't feel like they have the support to also confront the toxic white male.... We need our white allies, all our white allies, but particularly our elder white allies, to step up ... Do it strongly and do it so everyone else sees it, and do it so that the people of colour and the marginalized people in the room know that they have back up. That is, in many ways, what we didn't have during ShellNo. (Panelist 1)

Several panelists noted that the Grannies were well positioned to stand up to this behaviour (by deploying their white privilege and age-related moral authority) and that, by not intervening, they gave up opportunities to make space for racialized, Indigenous, and youth voices. Though this discussion unveiled some of the ways Grannies might have mis-stepped in their solidarity efforts, we observed a predominant sense of gratitude for the learning emerging from this conversation, among the Seattle Grannies and the wider audience. Panelist 1's remarks about needing white allies to step up to toxic white men in organizing spaces were repeatedly met with applause from the audience, including from the Seattle Grannies. In conversations following this panel, the Seattle Grannies expressed their commitment to keep working to do better in all the organizing spaces, and their new understanding of the specific roles they can play behind the scenes as older white women. With the exception of one comment in the Q \& A (from a Granny from elsewhere in the USA, defending the actions of racist police in protest spaces), all of the responses we witnessed from Grannies were rooted in their commitment to still learning.

This call on the Grannies to confront racism was also a call to confront how white knowledges (and the privileging of white knowledge's dominance and effectiveness) tend to scaffold organizing spaces in racist ways that go unchecked by white organizers like the Grannies (in line with Hunt \& Holmes, 2015). Panelist 2, for instance, explained that the presence and dominance of such toxic white males betray not only a difference in privilege and power, but also a friction in the very values and ideas that underpin activism. She explained that the Grannies have a responsibility to confront toxic white males, but also to confront how an implicit privileging of white ways of knowing seeps into organizing structures. Through this discussion, it became evident that the Grannies' positions did not render them inconsequential to climate justice organizing, but rather conferred specific roles for them as co-conspirators in all of the spaces and moments of the coalition. We also observed how the Grannies' missteps gave way to this important panel, which offered knowledges and relationship-building not only to the Seattle Grannies, but to the international network of Raging Grannies - a reminder of the importance of persisting relationships of solidarity through messiness and uncertainty. The Grannies' willingness to 
listen and learn from their mistakes catalyzed the panel's critical discussion about how intergenerational solidarity could be practiced within climate justice organizing widely, and about how age might be further mobilized by older activists to support youth leadership.

While this specific dialogue offered learning about the missed opportunities, the 2016 panel is also an example of how Grannies' solidarity practices extended into longer-standing relationship-building, learning, and listening outside of frontline action. That is, the Grannies were clearly still building relationships with coalition members at this Unconvention, one year after the ShellNo actions. And, in organizing this panel, they centred the knowledge of younger women of colour and Indigenous women while positioning themselves as learners and listeners. By design, the panel asked the Grannies in the audience to step back. Granny X introduced the panel as a way to extend her own learning from the coalition and to share this learning with Grannies around the continent, recognizing it as an unending process. As part of this process, the Grannies encouraged each other to sit with the discomfort of having their whiteness exposed and confronted:

We ask you, our Grannies in the audience, to do a few things. You may hear some things that make you uncomfortable. So, we ask you to be willing to experience discomfort; it's not always a bad thing. It can be a good thing to challenge and stretch ourselves.... If you do experience discomfort, do your best to be present and keep listening, rather than, for example, trying to think of responses. (Granny $\mathrm{X})$

The Grannies prioritized women of colour and Indigenous women on the panel, structuring it so that they would always speak first. This practice of prioritizing those whose voices are often less heard was also a broader approach to solidarity, modelling "some of the things that we Seattle Grannies learned through the whole ShellNo process" (Granny X). The panel itself, then, flipped age expectations of who is the knower/speaker and who is the learner/listener, while also challenging white-dominant assumptions about whose knowledge is most valid, authoritative, and legitimate (Margolin, 2019). Several panelists, particularly the first three, reinforced the idea that doing solidarity, for the Grannies, should involve this kind of ongoing cognitive work to unsettle their own epistemic certainty. In fact, Panelists 1 and 3 explicitly encouraged the Grannies to extend their solidarity into organizing spaces and through adopting daily lived practices of uncertainty that is, to ask themselves regularly why they believe they know, and how their knowledges might uphold colonial and white supremacist systems (Sholock, 2012).

Panelist 1's impact on Grannies became clear in the weeks following the Unconvention, which speaks to the Grannies' openness to learning to practice uncertainty, listen, and challenge their own epistemic dominance. This was evident through various email communications and Facebook posts from different Granny groups. Several Grannies stayed on in Seattle, for instance, 
to take a separate workshop from this panelist to learn more about decolonizing their own activist and solidarity practices. One Granny later shared with the network her own learning about the powerful effects of practicing solidarities that bring together while respecting political, cultural, epistemic, and experiential differences, beckoning other Grannies to draw on their learning to support Standing Rock mobilizations against the Dakota Access oil pipeline. Throughout these email exchanges, the tone was not to assume that there would be a role for the Grannies, or what that role should be, but to ask whether and how their presence or resources might be wanted always referring this approach back to the panelists' reflections.

This deepening conversation challenged assumptions that all older white women are uncritical white feminists (Chazan \& Baldwin, 2016) with no role in intersectional climate justice organizing, while further extending ways of doing solidarities into these internal processes of unsettling. Observing younger racialized activists taking this time with the Grannies also confounded popular presumptions that there is futility to investing in educating older people (Winter, 2017). Thus, we witnessed the Grannies extending their solidarity into nurturing relationships, continuing their learning, and embracing uncertainty. We also note how they entered into an even deeper process of rejecting expectations that they, as older white women, necessarily have expertise, by learning from younger Indigenous and racialized activists.

Lastly, Panelist 2's reflections (drawing on Indigenous epistemologies) further rupture the temporal and spatial limits typically imposed on understandings of activism and solidarity, even beyond organizing spaces and internal unsettling work, while extending intergenerational solidarity out to future generations:

What would I say to these people walking by who know nothing about what was going on? I would ask them, "What did you do when Shell Oil was here? What are you going to tell your grandkids 50 years from now? What part did you play in this?" So, I just want people to know that this work, it's our- It's not even about activism... It's my responsibility, it's my duty to do this work for the next seven generations. (Panelist 2)

Noting that dominant colonial knowledges inhibit this kind of cross-temporal solidarity, she called on audience members to instead enter into solidarities rooted not only in friendship and responsibility to one another, but also to ancestors past, generations to come, and to non-human relations. Extending thinking about intergenerational solidarities back and forward through time, she explained to the Grannies that taking on their responsibilities as the ancestors to generations to come would require them to shift their timeframe and goals well beyond immediate action and winnable coalition work. As she reflected, solidarity is not time-limited, it is not about one-off actions, nor is it about short-term goals. Instead, it is about caring for past, current, and future life, for human and non-human entities, for ancestors and those yet unborn, 
which all require expanding the goals, strategies, and assumptions that are often considered to be constitutive of solidarity. This idea also challenges old-versus-young polarizing age rhetoric to instead understand that we are all ancestors to future life, and we are all in relation to our own ancestors, with responsibilities to act accordingly (Flowers, 2015; Snelgrove, Dhamoon \& Corntassel, 2014). And, critically, her example illuminates how sometimes the motives behind acting in solidarity are conditioned by capitalist and colonial defaults that privilege products and outcomes over processes and relationships. This panelist asked the Grannies to consider how Indigenous knowledges might offer other ways of thinking about solidarities, expanding even further beyond tactical considerations and one-off actions.

Overall, then, the solidarity practices revealed in this research suggest that Grannies engaged in a temporally and spatially extended praxis of intersectional and intergenerational solidarity - on the frontlines, in organizing spaces, through transforming their thinking, and into the ancestral realm. Indeed, this multifaceted solidarity-building also requires unsettling the dominant epistemologies that tend to frame solidarity in such a temporally and spatially bounded way in the first place. What becomes important is that an isolated action or protest is not the only way of practicing solidarity; practicing being in meaningful relationships, making spaces for others, (un)learning, and listening are all also significant tactics (Sholock, 2012). And, critically, the Raging Grannies been invited into this work specifically from their positions as older white women.

\section{Conclusions}

While youth are leading climate justice uprisings around the world - and indeed have been engaged in this work for some time - dominant perceptions of them acting alone amid stark generational divides depict a far too simplistic version of these mobilizations. Yet, as noted, there exists limited analysis of how age and generation interweave dynamics of race, gender, class, ancestry, and geography within climate justice efforts or elsewhere in solidarity movements. As the Earth continues to heat up, it is crucial to better understand how intergenerational dynamics are, and could be better, practiced in climate justice mobilizing, and how age and aging can shape and strengthen solidarity building.

This article offers the example of the Raging Grannies and the ShellNo coalition as one entry point into this much-needed intergenerational and intersectional analysis - an example that illuminates grounded successes, missteps, practices, intentions, and lessons learned. In the ShellNo coalition, the Raging Grannies were invited into very specific roles related to their age, gender, and whiteness - roles that did not compromise, but rather honoured, the brilliance, energy, knowledges, and leadership of younger activists. On the frontlines, the Grannies deployed both their parody of ageist and sexist 
stereotypes and their white privilege to divert attention and confer protection to younger Indigenous and racialized activists. This frontline work was an example of meaningful tactical solidarity in action, and its practice was clearly infused with age dynamics. Beyond the frontlines, in other organizing spaces, younger coalition members suggested that the Grannies could have more proactively confronted sexism and racism by similarly drawing on the moral authority they hold as older white women. Such solidarity practices might have created space for racialized, Indigenous, and youth activists to offer even more behind-the-scenes leadership.

Where the Grannies were extending their solidarity practices beyond the frontlines was in their ongoing relationship-building with coalition members, as evident in the organizing of the panel discussion that opened their 2016 Unconvention. By situating themselves as learners/listeners and younger panelists as speakers/educators, they demonstrated a humbleness, or even a desire for humbleness, in their own knowing. The importance of this humbleness, particularly given their age and whiteness, was also reinforced by panelists. Panelists called on the Grannies to deepen their work toward unlearning the assumption that, as older white people, they have more experience and know best, and to learn from youth knowledges, racialized knowledges, and Indigenous knowledges. These reflections also indicated the panelists' investment in meaningful exchange with this network of older women, challenging assumptions of older white feminists as uncritical of their own privilege, assumptions that youth and racialized activists do not want or need support from older white people, and assumptions that older white women do not have a role in confronting racism (e.g., Chazan, 2016). Through these continued relationships, moreover, panelists invited the Grannies to carry their solidarities into an ever more temporally and generationally expansive practice; they challenged Grannies to reorient their activism, taking on ancestral responsibilities, and acting for all future life.

Our research contributes conceptually to scholarship on solidarity by bringing intersectional and intergenerational analyses together to offer insight into how age, race, and gender shape grounded solidarity practices (e.g., Brown \& Yaffe, 2014; Gaztambide-Fernández, 2012). It also extends conceptions of solidarity as praxis to include the internal work of unlearning white settler certainty (Sholock, 2012; Boudreau Morris, 2017). Importantly, we offer an example of how older people - attending to dynamics of age can be and are integral to critical, intersectional climate justice organizing. This kind of analysis is crucial to counteract rhetoric of generational divides. In this pivotal moment, generationally polarizing discourses are far too simplistic, and their tendency to incite and reify the divisions they portray is potentially dangerous to the kind of intergenerational and intersectional movement-building needed to protect life on this planet. 


\section{References}

Arvin, M, Tuck, E., \& Morill, A. (2013). Decolonizing feminism: Challenging connection between settler colonialism and heteropatriarchy. Feminist Formations, 25(1), 8-34

Bilge, S. (2011, Oct.). Developing intersectional solidarities: A plea for queer intersectionality. Equity Matters. Ottawa, ON: SSHRC. Retrieved from http://www.ideasidees.ca/blog/developing-intersectional-solidarities-plea-queer-intersectionality

Binnie, J., \& Klesse, C. (2012). The politics of age, temporality, and intergenerationality in transnational lesbian, gay, bisexual, transgender, and queer activist networks. Sociology, 47(3), 580-595.

Black, S. T., Milligan, R. A., \& Heynen, N. (2016). Solidarity in climate/immigrant justice direct action: Lessons from movements in the US South. International Journal of Urban \& Regional Research, 40(2), 284-298.

Boudreau Morris, K. (2017). Decolonizing solidarity: Cultivating relationships of discomfort. Settler Colonial Studies, 7(4), 456-473.

Brake, J. (2018, Oct.). 'Literally life and death': Indigenous climate leaders critical of Canada's response to climate change report. APTN National News. Retrieved from https://aptnnews.ca/2018/10/17/literally-life-and-death-indigenous-climate-leaders-criticalof-canadas-response-to-climate-change-report/

Brown, G., \& Yaffe, H. (2014). Practices of solidarity: Opposing Apartheid in the centre of London. Antipode, 46, 34-52.

Burton, N. (2019, Oct. 11). Meet the young activists of color who are leading the charge against climate disaster. Vox. Retrieved from www.vox.com/identities/2019/10/11/20904791/young-climate-activists-of-color

Cargle, R. (2018, Aug. 16). When feminism is white supremacy in heels. Harpers Bazaar. Retrieved from www.harpersbazaar.com/culture/politics/a22717725/what-is-toxic-whitefeminism/

Chazan, M. (2016). Settler solidarities as praxis: Understanding 'granny activism' beyond the highly visible. Social Movement Studies, 15(5), 457-470.

Chazan, M., \& Baldwin, M. (2016). Understanding the complexities of contemporary feminist activism: How the lives of older women activists contest the waves narrative. Feminist Formations, 28(3), 70-94.

Chazan, M., Baldwin, M., \& Evans, P. (2018). Unsettling activisms: Critical interventions on aging, gender, and social change. Toronto, ON: Women's Press.

Chazan, M., Baldwin, M., \& Whattam, J. (2018). Rethinking the politics of (grand)mothering: Activisms and the lifecourse. In M. Chazan, M. Baldwin \& P. Evans (Eds.), Unsettling Activisms (pp. 28-45). Toronto, ON: Women's Press.

Cohen, S. (2019, Feb.). The age gap in environmental politics. State of the planet. Retrieved from https://blogs.ei.columbia.edu/2019/02/04/age-gap-environmental-politics/

Cooper, D. (2014, Jan. 22). Generations of activism and queer time. JOTWELL. Retrieved from https://equality.jotwell.com/generations-of-activism-and-queer-time/

Council of Canadians. (2019, Apr. 30). Will you support the climate strike for the next generation? Council of Canadians [Weblog]. Retrieved from https://canadians.org/blog/will-you-support-climate-strike-next-generation

Democracy Now. (2015, June 16). 'Battling the Death Star': Seattle 'Kayaktivists' slow arcticbound Shell Oil rig as fight goes on. Democracy Now. Retrieved from www.democracynow.org/2015/6/16/battling_the_death_star_seattle_kayaktivists

Eisen, J., Mykitiuk, T., \& Scott, D. (2018). Constituting bodies into the future: Toward a relational theory of intergenerational justice. UBC Law Review, 51, n.p. Retrieved from http://digitalcommons.osgoode.yorku.ca/scholarly_works/2694

Featherstone, D. (2012). Solidarity: hidden histories and geographies of internationalism. London: Zed Books.

Flowers, R. (2015). Refusal to forgive: Indigenous women's love and rage. Decolonization: Indigeneity, Education \& Society, 4(2), 32-49. 
Frazer-Carroll, M. (2019, Sept.). On environmentalism, whiteness, and activist superstars. Galdem. Retrieved from http://gal-dem.com/on-individualism-whiteness-and-activistsuperstars/

Gaztambide-Fernández, R. A. (2012). Decolonization and the pedagogy of solidarity. Decolonization: Indigeneity, Education \& Society, 1(1), 41-67.

Goldman, M., Chazan, M., \& Baldwin, M. (2018). The Raging Grannies versus the sexperts: Performing humour to resist compulsory (hetero)sexuality. In M. Chazan, M. Baldwin, \& P. Evans (Eds.), Unsettling Activisms (pp. 153-169). Toronto, ON: Women's Press.

Greenfield, N. (2019). The path to climate justice is intergenerational. NRDC (National Resources Defense Council). Retrieved from https://www.nrdc.org/stories/path-climatejustice-intergenerational

Honor the Earth. (2019). Speaking engagements: Winona LaDuke. Retrieved from www.honorearth.org/speaking_engagements

Hunt, S., \& Holmes, C. (2015). Everyday decolonization: Living a decolonizing queer politics. Journal of Lesbian Studies, 19, 154-172.

IPCC (Intergovernmental Panel on Climate Change). (2018, Oct. 8). Special report: Global warming of $1.5^{\circ} \mathrm{C}$. Retrieved from www.ipcc.ch/sr15/

Kaijser, A., \& Kronsell, A. (2014). Climate change through the lens of intersectionality. Environmental Politics, 23(3), 417-433

Kaplan, S. (2015, June 10). Meet the 92-year-old 'raging granny' who just got arrested for protesting Arctic oil drilling. The Washington Post. Retrieved from www.washingtonpost.com/news/morning-mix/wp/2015/06/10/meet-the-92-year-oldraging-granny-who-just-got-arrested-for-protesting-arctic-oil-drilling

Langley, E. (2018). I will not use the word reconciliation-Exploring settler (un)certainty, Indigenous refusal, and decolonization through a life history project with Jean Koning [Unpublished masters thesis]. Trent University, Peterborough, ON.

Margolin, J. (2019, June 14). Patriarchy, racism, and colonialism caused the climate crisis [Video file]. Retrieved from www.youtube.com/watch?v=amGyIqIBzEk

Meadows, L. M., Thurston, S. E., \& Lagendyk, L. E. (2009). Aboriginal women at midlife: Grandmothers as agents of change. In P. A. Monture \& P. D. McGuire (Eds.), First voices: An Aboriginal women's reader (pp. 188-199). Toronto, ON: INANNA Publications \& Education Inc.

Mersha, S. (2018). Black lives and climate justice: Courage and power in defending communities and Mother Earth. Third World Quarterly, 39(7), 1421-1434.

Mohanty, C. T. (2003). Feminism without borders: Decolonizing theory, practicing solidarity. Durham, NC: Duke University Press.

Noisecat, J. B., \& Spice, A. (2016, Aug. 9). The history and future of resistance. Jacobin Magazine. Retrieved from www.jacobinmag.com/2016/09/standing-rock-dakota-accesspipeline-protest/

Olwan, D. M. 2015. On assumptive solidarities in comparative settler colonialisms. feral feminisms, 4, 89-102.

Paterson-Cohen, M. (2017, Nov. 10). The intersection of resilience, climate change, and aging. Critical Gerontology Blog. Retrieved from https://criticalgerontology.com/climate-changeaging/

Peltier, A. (2018, Mar. 22). Wikwemikong First Nation representative Autumn Peltier spoke to UN General Assembly. CBC News. Retrieved from www.cbc.ca/player/play/1192177731983/

Regan, P. (2010). Unsettling the settler within. Vancouver, BC: UBC Press.

Rowe, J., \& Simpson, M. (2017, Oct. 9). Lessons from the frontlines of anti-colonial pipeline resistance. Waging NonViolence. Retrieved from https:/wagingnonviolence.org/feature/lessons-front-lines-anti-colonial-unistoten-pipelineresistance/

Roy, C. (2004). The Raging Grannies: Wild hats, cheeky songs, and witty actions for a better world. Montreal, QC: Black Rose Books. 
Ryan, J. (2015, May 18). Hundreds of 'kayaktivists' in Seattle protest Shell's arctic drilling. $N P R$. Retrieved from www.npr.org/2015/05/18/407619645/hundreds-of-kayaktivists-inseattle-protest-shells-arctic-drilling

Sawchuk, D. (2009). The Raging Grannies: Defying stereotypes and embracing aging through activism. Journal of Women \& Aging 19, 171-185.

Shell, L. 2019. Intergenerational activism: Achieving environmental justice. The Bubble. Retrieved from www.thebubble.org.uk/current-affairs/intergenerational-activismachieving-environmental-justice/

Sholock, A. (2012). Methodology of the privileged: White anti-racist feminism, systematic ignorance, and epistemic uncertainty. Hypatia, 27(4), 701-714.

Snelgrove, C., Dhamoon, R. K., \& Corntassel, J. (2014). Unsettling settler colonialism: The discourse and politics of settlers, and solidarity with Indigenous nations. Decolonization: Indigeneity, Education, \& Society, 3, 1-32.

Tait, A. (2019, June 6). Greta Thunberg: How one teenager became the voice of the planet. WIRED. Retrieved from www.wired.co.uk/article/greta-thunberg-climate-crisis

Tormos, F. (2017). Intersectional solidarity. Politics, Groups \& Identities, 5(4), 707-720.

United Nations. (2017, Oct. 27). Listen to the Children - Severn Cullis-Suzuki's famous speech on the environment (1992) [Video file]. Retrieved from www.youtube.com/watch? $\mathrm{v}=\mathrm{JGdS} 8 \mathrm{ts} 63 \mathrm{Ck}$

Walia, H. (2012). Moving beyond a politics of solidarity towards a practice of decolonization. In A. Choudry, J. Hanley \& E. Shragge (Eds.), Organize! Building from the local for global justice (pp. 240-253). Toronto, ON: Between the Lines.

Water Docs. (2019a, Mar. 15). How one girl from Sweden sparked a global youth-led climate movement. Water Docs. Retrieved from www.waterdocs.ca/water-talk/2019/3/15/how-onegirl-sparked-a-global-climate-movement

Water Docs. (2019b, Mar. 8). The women who walk for the water: Grandmother Josephine Mandamin's legacy. Water Docs. Retrieved from www.waterdocs.ca/news/2019/3/8/thewomen-who-walk-for-the-water-grandmother-josephines-legacy

Winter, C. J. (2017). The paralysis of intergenerational justice: Decolonizing entangled futures [Unpublished doctoral dissertation]. University of Sydney, Sydney, AU. Retrieved from https://ses.library.usyd.edu.au/bitstream/handle/2123/18009/winter_cj_thesis.pdf?sequence $=1 \&$ isAllowed $=\mathrm{y}$ 